\title{
EPIZOOTIOLOGICAL SITUATION OF AFRICAN SWINE FEVER IN EUROPE
}

\author{
Vesna Milićević1 ${ }^{1 \star}$, Vladimir Radosavljević1 ${ }^{1}$ Ljubiša Veljović ${ }^{1}$, \\ Jelena Maksimović-Zorić ${ }^{1}$, Sonja Radojičić ${ }^{2}$ \\ ${ }^{1}$ Institute of Veterinary Medicine of Serbia, Virology Department, Belgrade, Serbia \\ ${ }^{2}$ Faculty of Veterinary Medicine, Department of Infectious \\ Animals Diseases and Diseases of Bees, Belgrade, Serbia
}

\section{Abstract}

African swine fever (ASF) is a viral disease of domestic pigs and wild boar. Due to the very serious socioeconomic consequences, the disease is one of the most important ones nowadays. African swine fever is an enzootic disease in many countries in Sub-Saharan Africa, in Sardinia, and Trans Caucasus countries. After its occurrence in Georgia in 2007, ASF spread to Armenia and Russian Federation, and in 2008. to Azerbaijan. Since then, its progressive moving toward the west has been recorded. Despite the number of undertaken preventive and control measures in the European Union (EU), ASF has been still spreading. During 2017, the disease has been reported in domestic pigs in Estonia, Italy-Sardinia, Latvia, Lithuania, Poland, Romania, and Ukraine. ASF cases in domestic pigs have also been reported in Moldova in 2017. The number of diagnosed cases in wild boar in 2017 is much higher than in domestic pigs. ASF outbreak in wild boar in the Czech Republic well describes the possible viral ,jump" into a new region. The source of infection hasn't been confirmed yet, but it is common that such leaps are due to either swill feeding or improperly disposal of food rather than to the animal movements. Since the lack of effective vaccine makes eradication even more difficult, the prevention of viral entry into the new areas is of the most importance. With the same aim, since 2011.the surveillance of ASF has been implemented in Serbia.

Key words: African swine fever, domestic pigs, wild boar

${ }^{1 *}$ Corresponding author: vesna.milicevic@nivs.rs 


\title{
EPIZOOTIOLOŠKA SITUACIJA AFRIČKE KUGE SVINJA U EVROPI
}

\author{
Vesna Milićević ${ }^{1 *}$,Vladimir Radosavljević ${ }^{1}$, Ljubiša Veljović ${ }^{1}$, \\ Jelena Maksimović-Zorić ${ }^{1}$, Sonja Radojičić ${ }^{2}$ \\ ${ }^{1}$ Naučni institut za veterinarstvo Srbije, Odeljenje za virusologiju, Beograd, Srbija \\ ${ }^{2}$ Fakultet veterinarske medicine, Katedra za zarazne \\ bolesti životinja i bolesti pčela, Beograd, Srbija
}

\section{Kratak sadržaj}

Afrička kuga svinja (AKS) je virusna bolest domaćih i divljih svinja. Socioekonomske posledice ove bolesti svrstavaju je u najznačajnije bolesti današnjice. Afrička kuga svinja je enzootska bolest u mnogim zemljama južno od Sahare, na Sardiniji i Kavkazu. Pošto se pojavila 2007. godine u Gruziji, AKS se iste godine proširila na Jermeniju i Rusiju, a 2008. na Azerbejdžan. Od tada se beleži progresivno kretanje virusa ka zapadu. Uprkos svim preventivnim i kontrolnim merama koje se sprovode u Evropskoj uniji (EU), afrička kuga svinja se i dalje širi. Tokom 2017. godine kod domaćih svinja je dokazana u Estoniji, Italiji - Sardinija, Letoniji, Litvaniji, Poljskoj, Rumuniji i Ukrajini. Slučajevi AKS kod domaćih svinja u Moldaviji su takođe registrovani i u 2017. godini. Broj dijagnostikovanih slučajeva kod divljih svinja u 2017. je značajno veći u odnosu na broj slučajeva kod domaćih. Pojava AKS u Češkoj 2017. godine kod divljih svinja predstavlja veliki „skok“ virusa u novo područje. Izvor infekcije još uvek nije potvrđen, ali je uobičajeno da se ovakve pojave dešavaju kao posledica hranjenja životinja ostacima hrane, a ne zbog kretanja životinja. Budući da je iskorenjivanje AKS veoma otežano u odsustvu efikasne vakcine, prevencija unosa virusa u nova područja je od najvećeg značaja. Sa tim ciljem, u Srbiji se od 2011. godine sprovodi nadzor kod divljih svinja na afričku kugu.

Ključne reči: afrička kuga svinja, domaće svinje, divlje svinje

\section{INTRODUCTION}

African swine fever (ASF) is a viral disease of domestic pigs and wild boar. Due to the very serious socioeconomic consequences, the disease is one of the most important ones nowadays. Clinical symptoms vary depending on viral virulence and immune status of the host.

In European both domestic and wild pigs, ASF usually has the acute course with mortality $95-100 \%$ (Gallardo et al., 2015). Unlike in European species, in 
African wild suids, the disease is subclinical and asymptomatic enabling them to be the reservoir of the virus.

However, soft ticks from the genus Ornitodoros are considered as the natural host and also vectors and reservoirs of the virus (Plowright et al., 1969). Ornithodoros moubata ticks are the vectors in the east and South Africa and Indian Ocean islands where the disease was confined until 2007. After 2007, despite the absence of competent vectors and reservoirs, the disease has been progressively spreading throughout Eurasia (Gallardo et al., 2015).

African swine fever was discovered in Kenya in 1909 after the European breeds of domestic pigs had been imported (Penrith et al., 2013). At that time, it was described as a haemorrhagic disease, causing almost total mortality of the domestic pigs. After its discovery, it has been confirmed that the causal agent had been circulating in the east and south Kenya since long ago in wild suids. Though later on the disease was reported in the other parts of Africa, geographically it was confined to Sub-Saharan region.

ASF occurred in Portugal in 1957, for the first time out of Africa, incurring from the west of Africa. After the two years of silence, it re-occurred in Portugal from where it has rapidly spread to the rest of Iberian Peninsula and other European countries - France (1964), Italy (1967, 1969, and 1983), Malta (1978), Belgium (1985) and the Netherlands (1986). During this period, ASF has been recorded also in central and south America - Cuba (1971, 1980), Brazil (1978), Dominican Republic (1978) and Haiti (1979). All those countries eradicated ASF, with the exception of Sardinia.

\section{AFRICAN SWINE FEVER VIRUS}

African swine fever virus is the only member of the family Asfaviridae and genus Asfivirus. It is a very complex DNA virus with 4 layers envelope (Dixon et al., 2005). The genome, 170-193 kbp long, possess 151-167 open reading frames (ORF) and codes 54 proteins and 100 polypeptides (Dixon et al., 2013). The capsid protein (p72) and two structural proteins, p30 and p54, are the most important ones. As the polyprotein pp62 is immunodominant, the antibodies generated after the natural infection are directed against it (Pastor et al., 1989). As of yet, 22 genotypes and 8 serogroups have been described (Gallardo et al., 2011). ASFV is very resistant to inactivation. However, many disinfectants such as lipid solvents, phenol, and iodide inactivate the virus at $\mathrm{pH}$ lower than 4 and higher than 11. The virus survives several weeks in the frozen or fresh meat as well as in the meat products. The temperature above $70{ }^{\circ} \mathrm{C}$ inactivates the virus (Sánchez-Vizcaínoa et al., 2009). 


\section{GEOGRAPHIC DISTRIBUTION}

African swine fever is an enzootic disease in many countries in Sub-Saharan Africa, in Sardinia and Trans Caucasus countries. The virus in Africa circulates between wild suids and soft ticks. The disease is inapparent in the warthog, bush pig, and red river hog; the viremia in those species is at very low or even undetectable level but it does enable the infection of ticks (Jori and Bastos, 2009). In Europe, ASF is enzootic in Sardinia in wild boar population despite no soft ticks. Unlike in the past, today the viral circulation is being accomplished through 4 cycles - sylvatic cycle between ticks and wild boars, cycle between ticks and domestic pigs, viral circulation between domestic pigs and viral circulation between wild boars (Pietschmann et al., 2016). African swine fever occurred in 2007 in Georgia and afterward in other Trans Caucasus countries and Russian Federation as well, having destroyable effects on swine production (Rowlands et al., 2008). The incursion of ASF in this region has been linked to the international overseas transport between Africa and Georgia and swill feeding of pigs in the area surrounding the ports. After its occurrence in Georgia in 2007, ASF spread to Armenia and Russian Federation, and in 2008 to Azerbaijan. Since then the disease has progressively been moving toward the west: Ukraine (2012), Belorussia (2013), EU countries Lithuania, Poland, Latvia and Estonia (2014), Moldova (2016), Czech Republic (2017), and Romania (2017). However, the competent vectors from the Ornithodoros moubata complex in this region have not been found. Ticks from the $O$. erraticus complex and O. tholozani have been found in some Mediterranean countries (Portugal, Spain, Italy, and Turkey) and Black sea countries (Moldova, Romania, and Georgia), Armenia, and Azerbaijan. Though those tick species have not been known as important for the disease spreading, they could be important for the maintenance of the infection in an area (Ravaomanana et al., 2010).

\section{PATHOGENESIS}

ASFV infection of ticks in Africa is characterized by low infectious dose, lifelong infection and low mortality rate until the first laying of eggs. Unlike them, Ornithodoros ticks from the central and South America and Caribbean region show relatively high mortality of nymphs while the infection is not lifelong (Kleiboeker and Scoles, 2001). Ornithodoros ticks live up to 20 years enabling continuous viral maintenance in nature and in traditional pig keeping systems (Kleiboeker and Scoles, 2001). However, ticks have no role in long- 
distance viral spreading but they do link the sylvatic ASF with the domestic pigs in Africa.

The most common infection routes in pigs are nasal and oral, with the exception of the dermal route in Africa via infected ticks. Once the disease has been established in a new area, the virus is usually transmitted through direct contact. Carriers, also, significantly contribute to the indirect routes of infection - via vehicles, rodents, equipment, people etc. Usually, incubation takes 4-19 days (Gallardo et al., 2015). Viral excretion in all excretes starts 2 days before the onset of the clinical symptoms and it can last up to 70 days. The extremely high viral titer is being found in the blood. The acute disease, clinically manifested, terminates within 4-5 days (Gallardo et al., 2015). Peracute and acute courses, with the high lethality, are common for the beginning of the epizootic. With the disease progression, more subacutely and chronically diseased animals are being found. At the same time, the viral virulence and mortality are decreasing. Infected pigs, usually, live several weeks but some of them can survive. Having the subclinical infection, they can live for a longer period of time. Survivals, persistently infected, with no clinical symptoms, play very important role in the disease maintenance in the enzootic regions and sporadic outbreaks in the new areas, as well.

\section{CURRENT EPIZOOTIC SITUATION}

Countries with the intensive pig production are the most vulnerable ones. Pigs, due to the fast growth, efficient feed conversion, and the fast turnover became the most important protein source for the human population. The majority of pig production is located in China, south-east Asia, west Europe, central and eastern USA, Americas, and south Brazil. However, there is still a deep gap between traditional and industrial pig production. African pig production is concentrated in Sub Saharan Africa, mostly in small family farms.

Though ASF had been existing in the majority of African countries, since 1995. a significant increase of outbreaks in Sub Saharan Africa and spreading into the free countries Madagascar and Mauritius were reported (Beltrán-Alcrudo et al, 2017). Those expansion of the disease along with the low awareness were the key factors for the viral incursion in the countries out of Africa in 2007. The transmission of ASF in Africa is very complex, depends on reservoirs, ticks, domestic pigs, the breeding system and human habits.

Since the first occurrence in 2007, ASF turned into large-scale epizootic in Europe and the part of Asia.

Beside of that, there are two distinguishable enzootic zones in Russia 
Federation, in the central and in the southern part of the country (Gogin et al., 2013). There is, also, the evidence of survival wild boars. Such animals have no manifested clinical symptoms but could develop carrier status, enabling viral maintenance and spreading. In those regions, along with the appearance of sub clinically diseased wild boars, the mortality has been decreasing due to the acquired immunity, low infectious dose, viral adaptation to the new host and/ or positive selection of lower virulent strains which normally appear after long time circulation in one population.

Non-EU countries combat with the ASF trying hard to stop it but the applied measures are apparently not efficient and do not prevent the viral spreading. The trade chains of cheap swine products, originating from the infected regions, are recognized as the major transmission routes of the ASF (BeltránAlcrudo et al., 2017). The leftovers of such products, usually improperly disposed or given to the pigs in swill, are the link between ASF and domestic pigs.

Almost since the first case of ASF in 2007, the preventive measures and surveillance have been implemented in EU (Gallardo et al., 2015). Along with the disease progression, the crisis plans have been updated in order to provide as earliest as possible disease detection. Currently applied preventive measures include regionalisation according to the World Trade Organisation, disinfection of vehicles at borders, strict controls at borders, ban of fairs, strict application of biosecurity measures, awareness campaigns, increase of number of tested animals, protective zones establishment, decrease of wild boar population, establishment of fruitful communication between the field and laboratories, promotion of necessary epizootic investigations etc. Nevertheless, it has been shown that the disease is possible to be put under control, like it has been since 2 decades in Sardinia, with no excursion out from the island.

Unlike in Russian Federation where ASF is mostly found in domestic pigs, wild boars are more affected in EU. Though it is assumed that ASF in EU has been spreading locally and independently in each, wild boar and domestic pigs, all cases in the domestic swine population were registered in the areas inhabited with both domestic and wild swine despite no contacts between them. Therefore, low biosecurity and swill feeding are considered as the most important routes of the viral introduction into the pig farms. ASF in domestic pigs occurred in EU in 2014 in Lithuania (Gallardo et al., 2015). It has been shown that for the efficient disease eradication, the early detection was a crucial factor. At the beginning of the epizootic in Lithuania, only sudden deaths were reported. Therefore, in high-risk areas, in the case of sudden deaths, ASF needs to be excluded. Viral transmission within the affected farm was further directed according to the type of the farm and applied biosecurity measures. 
Apart from the sudden deaths, other clinical symptoms must not be overlooked, in particular, fever even in a small number of animals. In EU, considering intensive and modern pig production, the special concern has been put on wild boar in regard to viral maintenance and the spread. However, their exact role has not been fully described so far. In Caucasus and Russian Federation, inhabited by the low dense wild boar populations, ASF was not persisting for a long time despite continuous viral introductions from the domestic pigs. With the disease progression toward the west and the high dense wild boar populations such as in Poland and Baltic countries, wild boars become more important particularly because of continuous disease occurrence (Beltrán-Alcrudo et al, 2017).

The majority of cases have been discovered during the summer time. Even in cold climates where the temperature during the winter stays below $0{ }^{\circ} \mathrm{C}$, ASF is usually found in the warmer periods after the melting of infected cadavers. Still, there are two peaks of ASF in wild boars -winter and summer one. By using the spatiotemporal analytical methods, it has been determined that ASF spreads $2 \mathrm{~km}$ by month in Latvia and Estonia and $1 \mathrm{~km}$ monthly in Lithuania and Poland (Abrahantes et al., 2017).

By using the statistic models, it has been shown that both the virus and antibody prevalence have been increasing since 2014 in hunted wild boars in Estonia and Latvia, with the maximum in the winter time. The largest number of dead animals has been found during the summer due to the specific biology of wild boar. The virus prevalence in hunted wild boars is at low level - 0.5-3\%. In found dead wild boars, it is 60-80\% in Estonia, Latvia, and Lithuania but only 0.04-1.42\% in Poland (Abrahantes et al., 2017). Since the start of the epizootic, the virus prevalence is higher than the seroprevalence in hunted animals. The linkage between ASF occurrence and the factors considered as risky, such as the number of populated places, human population size, number of domestic pigs and farms, roads net, forestation, wild boars habitats, has been investigated. It has been shown that the strongest link exists between ASF occurrence and the size of human population. The wild boar population density was considered as an important factor only in Estonia in the period 2014-2016 (Abrahantes et al., 2017). Despite many efforts and resources put into active surveillance and early detection of ASF, it has been shown that the passive surveillance was more efficient. All primary cases were discovered within passive surveillance.

Even though carriers in wild boar have not been found so far in EU, there are different ways which enable a long-term viral circulation. They are usually human-mediated: illegal trade of animals and animal products, low biosecurity level, and wild boars feeding (Abrahantes et al., 2017). Beside of those, cadavers 
of infected animals serve also as a source of the infection (Probst et al., 2017).

The most probably, ASF spreads between subpopulations of wild boars by contact with the infectious materials (blood, cadaver, excretes). However, there is moderate to high likelihood that the direct contact between wild boars is crucial for the viral transmission, in particular where the feeders are in place. Moderate to high likelihood is applied also in case of finding improperly disposal of food leftovers (EFSA, 2015). Considering the consequences of ASF, different strategies to stop its spread have been implemented. One of them is the reduction of wild boar population. But, as every human intervention in nature, this one also produced the certain consequences. Intensive and often hunt during the depopulation campaigns lead to the wild boar dispersion and the disease spread. Reduction of a population for the more than $60 \%$ drives to the wild boar adaptation, the compensatory growth of the number of animals, and intensive movements out of the hunting area (EFSA, 2015).The feeding of wild boars prevents their dispersion but leads, due to their grouping, to the pathogens exchange. More effective measure for the control of wild boar population is the ban of feeding along with intensified hunting during the several consecutive years, aiming to reduce the number of females of all categories.

Therefore, there are two recommended types of managing wild boar populations: 1. Fast control measures meaning depopulation (killing over $70 \%$ of wild boars) or rapid disposal of carcasses, 2. Long-term measures meaning ban of feeding and hunting of females (EFSA, 2015).

However, despite all undertaken preventive and control measures, ASF has been still spreading. During 2017 it has been reported in domestic pigs in Estonia ( 3 cases), Italy - Sardinia (17 cases), Latvia (8 cases), Lithuania (30 cases), Poland (80 cases), Romania (2 cases) and Ukraine (110 cases). ASF in domestic pigs has also been registered in Moldova in 2017.Number of cases in wild boars is even higher - Czech Republic (115 cases), Estonia (542), Italy - Sardinia (28 cases), Latvia (749 cases), Lithuania (794 cases), Poland (398 cases), Ukraine (17 cases) $)^{1}$. AFS outbreak in the Czech Republic represents a huge „jump" of the virus into the new region. Though the source of the infection has not been documented yet, such events usually happen because of swill feeding or improper disposal of food leftovers. Two cases of ASF in domestic pigs in Romania, also, prove this.

Since the eradication of ASF is even more complex due to no vaccine availability, prevention of viral introduction is the most important. Having this as an aim, since 2011 there are implemented active and passive surveillance of ASF in Serbia (19). Considering both small wild boar population in Serbia

${ }^{1}$ https://ec.europa.eu/food/sites/food/files/animals/docs/ad_adns_outbreaks-per-disease.pdf 
and traditional pig keeping despite the absence of competent tick vector species (20), ASF would produce destructive consequences for small producers. However, along with the surveillance and having learned lessons from the other countries, additional efforts are to be put into awareness and education of farmers, producers, and population in general.

\section{REFERENCES}

1. Abrahantes J.C., Gogin A., Richardson J., Gervelmeyer A.: Epidemiological analyses on African swine fever in the Baltic countries and Poland. EFSA Journal, 15, 3, 4732, 2017.

2. Beltrán-Alcrudo D., Arias M., Gallardo C., Kramer S., Penrith M.L.: African swine fever: detection and diagnosis - A manual for veterinarians. FAO Animal Production and Health Manual, 19, 2017.

3. Dixon L.K., Chapman D.A., Netherton C.L., Upton C.: African swine fever virus replication and genomics. Virus Research, 173, 1, 3-14, 2013.

4. Dixon L.K., Escribano J.M., Martins C., Rock D.L., Salas M.L., Wilkinson P.J.: Asfarviridae. In: Mayo M.A., Maniloff J., Desselberger U. Virus Taxonomy, VIII. Report of the ICTV Elsevier. London: Academic, 135-143, 2005.

5. EFSA AHAW Panel (EFSA Panel on Animal Health and Welfare): Scientific opinion on African swine fever, EFSA Journal, 13, 7, 4163, 2015.

6. Gallardo C., Okoth E., Pelayo V., Anchuelo R., Martin E., Simon A., Llorente A., Nieto R., Soler A., Martin R., Arias M., Bishop R.P.: African swine fever viruses with two different genotypes, both of which occur in domestic pigs, are associated with ticks and adult warthogs, respectively, at a single geographical site. Journal of General Virology, 92, 432-444, 2011.

7. Gallardo C., Reoyo A.T., Fernández-Pinero J., Iglesias I., Muñoz J., Arias L.: African swine fever: aglobal view of the current challenge. Porcine $\mathrm{He}$ alth Management, 1, 21, 2015.

8. Gogin A., Gerasimov V., Malogolovkin A., Kolbasov D.: African swine fever in the North Caucasus region and the Russian Federation in years 2007-2012. Virus Resarch, 173, 198-203, 2013.

9. Jori F., Bastos A.D.S.: Role of Wild Suids in the Epidemiology of African Swine Fever. EcoHealth, 6, 2, 296-310, 2009.

10. Kleiboeker S.B., Scoles G.A.: Pathogenesis of African swine fever virus in Ornithodoros ticks. Animal Health Research Review, 2, 2, 121-128, 2001.

11. Milicevic V., Veljović Lj., Maksimović - Zorić J.: Afrička kuga svinja. Zbornik radova, Symposium XVI Epizootiology days of Serbia, 6 - 7. November, Zrenjanin, 2014. 76-77. 
12. Milicevic V., Maksimovic-Zoric J., Veljovic Lj., Pavlovic I.: Viral Vector Borne Diseases: Early Detection And Risk Analysis. Proceedings, Second International Symposium of Veterinary Medicine, 22 -24. June, Belgrade: Scientific Institute of Veterinary Medicine of Serbia, 2016, 16-23.

13. Pastor M., Laviada M., Sánchez-Vizcaíno J.M., Escribano J.: Detection of African swine fever virus antibodies by immunoblotting assay. Canadian Journal of Veterinary Research, 53, 105-107, 1989.

14. Penrith M.L., Vosloo W., Jori F., Bastos A.D.: African swine fever virus eradication in Africa. Virus Research, 173, 228-246, 2013.

15. Pietschmann J., Mur L., Blome S., Beer M., Pérez-Sánchez R., Oleaga A., Sánchez-Vizcaíno J.M.: African swine fever virus transmission cycles in Central Europe: Evaluation of wild boar-soft tick contacts through detection of antibodies against Ornithodoros erraticus saliva antigen. $B M C \mathrm{Ve}-$ terinary Research, 12, 1, 2016.

16. Plowright W., Parker J., Peirce M.A.: African swine fever virus in ticks (Ornithodoros moubata, murray) collected from animal burrows in Tanzania. Nature, 221, 1071-1073, 1969.

17. Probst C., Globig A., Knoll B., Conraths F.J., Depner K.: Behaviour of free ranging wild boar towards their dead fellows: potential implications for the transmission of African swine fever. Royal Society Open Science, 4, 170054, 2017.

18. Ravaomanana J., Michaud V., Jori F., Andriatsimahavandy A., Roger F., Albina E., Vial L.: First detection of African swine fever virus in Ornithodoros porcinus ticksin Madagascar and new insights into tick distribution and taxonomy. Parasites and Vectors, 3, 115, 2010.

19. Rowlands R.J., Michaud V., Heath L., Hutchings G., Oura C., Vosloo W., Dwarka R., Onashvili T., Albina E., Dixon L.K.: African swine fever virus isolate, Georgia, 2007. Emerging Infectious Diseases, 14, 12, 1870-1874, 2008.

20. Sánchez-Vizcaínoa J.M., Martínez-Lópeza B., Martínez-Avilés M., Martins C., Boinas F., Vialc L., Michaud V., Jori F., Etter E., Albinac E., Roger F.: Scientific reviews on classical swine fever (CSF), African swine fever(ASF) and African horse sickness (AHS), and evaluation of the distribution of arthropod vectors and their potential for transmitting exotic or emerging vector-borne animal diseases and zoonoses. EFSA Scientific Opinions, $1-141,2009$. 